УДК 101.1:378.4-029.9

\title{
ЭВОЛЮЦИЯ ИДЕИ УНИВЕРСИТЕТА
}

\author{
Сантоцкая Ксения Эдуардовна ${ }^{1,2}$, \\ santotskayak@mail.ru
}

\author{
${ }^{1}$ Национальный исследовательский Томский политехнический университет, \\ Россия, 634050, г. Томск, пр. Ленина, 30 \\ 2 Томский государственный педагогический университет, \\ Россия, 634061, г. Томск, ул. Киевская, 60
}

\begin{abstract}
Сантоцкая Ксения Эдуардовна, аспирант Школы базовой инженерной подготовки Национального исследовательского Томского политехнического университета; старший преподаватель кафедры экономической теории Томского государственного педагогического университета.
\end{abstract}

\begin{abstract}
Актуальность. Становление системы высшего образования и развитие идеи университетов имеют многовековую историю. Изучение эволюции идеи университета позволяет понять, как влияет изменение университетов на жизнь общества, организацию обучения студентов и эволюцию в целом. Анализ идеи университета способствует пониманию тенденций, к ко торым стремится система высшего образования, а знание этих тенденций помогает видеть перспективы развития общества. Исследование системы высшего образования в Российской Федерации позволяет понять историю и формирование предпосылок для дальнейшего развития системы высшего образования. Изучение моделей университетов, в том числе современных, определяет векторы развития высших учебных заведений в транзитивном обществе. Целью исследования является изучение изменения идеи университетов и определение тенденций развития современных университетских моделей. Методы: аналитический, исторический, компаративистский. Результаты. Выявлены тенденции развития современных университетов; изучены перспективы и принципы развития модели «Университет 4.0» и ее отличия от действующей на сегодняшний день модели; определены характеристики университетов, способствующих успешной адаптации высших учебных заведений к постоянно меняющимся запросам современного мира.
\end{abstract}

Ключевые слова: Университет, высшее образование, трансформация университетов, модель университета, развитие университетов, транзитивное общество, тенденции развития высшего образования.

История и идея университетов, а также история университетского образования начали развиваться в Средневековье. «Первыми прообразами» университетов были такие центры науки и культуры античности, как Академия Платона, Ликей Аристотеля и Александрийский мусейон. В средневековой Европе существовали монастырские школы еще до появления университетов, но в полной мере они не готовили необходимых специалистов. Поэтому в крупных городах начинают появляться городские начальные школы, такие как магистратские, цеховые, гильдейские [1]. В таких школах дети обучаются счету, родному языку, латыни. Но в дальнейшем появилась необходимость в открытии институтов, дающих высшее образование. Возникновению университетов в Средние века способствовали упадок монастырских школ и стремительное развитие городов. Была сформирована и формализована институциональная модель либерального университета [2]. Данная модель исходила из представлений об университете как об учреждении, которое обеспечивает студентов жизненными ориентирами и определенным мировосприятием посредством накопления, сохранения и передачи универсального знания. 
Общественная миссия либерального университета заключалась в обучении достижениям культуры, развитии интеллекта и духовности, формировании интеллектуальной элиты общества [3].

В конце XI - начале XII в. отдельные кафедральные и монастырские школы превращались в крупные учебные центры. В результате возросшей потребности как в научном знании, так и в ученых начался процесс образования высших школ - университетов на базе соборных школ в крупнейших городах Западной Европы. К середине XIII в. в Европе сложилась единая система университетов.

Первоначально понятие «университет» (от лат. universitas - совокупность) означало корпорацию преподавателей, профессоров и студентов, «схоларов», целью которой являлось изучение и приумножение единого христианского знания [4].

В первых средневековых университетах (Болонья, Париж, Кембридж, Оксфорд, Лиссабон) были сформулированы основные принципы академической автономии, а также разработаны демократические правила управления высшей школой и ее внутренней жизнью. Так, университеты имели ряд привилегий, дарованных им Папой Римским, таких как выдача разрешений на преподавание, присуждение ученых степеней, освобождение студентов от военной службы, а сами учебные заведения - от налогов. Обычно средневековые университеты имели четыре факультета. Обязательным для всех был общеподготовительный факультет. После изучения грамматики, риторики и основ диалектики студент получал степень бакалавра искусств, а по изучении полного курса (философии, арифметики, геометрии, астрономии и теории музыки) ему присваивалась степень магистра искусств. Обучение на данном факультете могло начинаться с 15-16 лет. Как правило, магистрантами могли стать люди не моложе 21 года, проучившиеся не менее 5-7 лет. Магистрантам предоставлялось право преподавания и поступления на один из трех факультетов: богословский (теологический), медицинский или юридический. Обучение на медицинском и юридическом факультете продолжалось 7-9 лет, на теологическом - 12-15 лет. По окончании выбранного факультета магистранту присваивалась та или иная степень по соответствующей отрасли [5].

Организация занятий в университетах включала в себя чтение утренних лекций, в ходе которых преподаватели читали вслух тексты, формулировали проблему и разбивали её на более частные проблемы. Вечером другие преподаватели в своих лекциях обращались к тем же темам или к более узким проблемам. Огромное значение в обучении придавалось умению формулировать вопросы. Еженедельно проводились диспуты, с помощью которых формировалась способность вести полемику. В то время наибольшее развитие получили юридические факультеты, где изучали каноническое и римское право [6].

Университеты Средневековья сформировали культуру, в основе которой лежало признание за учёными особой роли в жизни общества - сохранение внутреннего единства христианского мира. Основным в Средние века стал религиозный стиль мышления. Основанием ему служило именно наличие веры, а не наблюдения и доказательства. Несмотря на это в обществе осуществлялся рост знаний, происходили новые географические открытия. Это способствовало преобладанию роли разума в познавательной деятельности, обеспечивающему постепенное оттеснение нерациональных методов на второй план и переход к рациональным методам освоения мира.

Вся система университетского образования оказала сильное влияние на формирование западноевропейской цивилизации. Университеты способствовали прогрессу научной мысли, росту общественного самосознания и свободы личности. В XIV-XVI вв. в Западной и Центральной Европе расширяется сеть университетов, а уже в конце XVII в. высшее образование стало рассматриваться как необходимое условие социального продвижения, карьеры, достижения жизненного и профессионального благополучия. 
Средневековые университеты можно отнести к идее классического университета или модели 1.0. Можно сказать, что классический университет представляет собой сложную образовательную систему, характерными чертами которой являются: высокий уровень подготовки студентов и преподавателей; оптимальное сочетание естественнонаучных и гуманитарных дисциплин в направлениях обучения; формирование у выпускников способностей к созданию и поддержанию культурных и нравственных ценностей [7].

Что касается развития системы высшего образования Европы XVII-XVIII вв., то важным аспектом развития высшего образования стало то, что началось соединение гуманитарной культуры с естественными науками. Также в содержание образования стали широко входить естественные науки. Начиная с XVII в. в европейских государствах начинают создаваться специальные высшие школы и институты: лесные, военные, педагогические, сельскохозяйственные и т. д. Кроме того, в Европейских университетах в XVIII в. начинается переход на национальные языки [8].

C середины XVIII в. действующая на то время модель университета начала подвергаться критике в связи с применением теоретического обоснования жизненного опыта преподавателей и неиспользованию практического опыта при выдвижении тех или иных суждений. Система высшего образования отставала от достижений других интеллектуальных центров того времени. А уже к концу XVIII столетия необходимость статуса университета как главного образовательного и научного центра ставилась под сомнение по всей Европе. Так, например, с 1789 по 1815 г. количество университетов в Западной Европе сократилось со 143 до 83. Во Франции были ликвидированы 24 университета, еще 12 трансформированы в специальные высшие учебные заведения. Из 34 немецких университетов остались только 18, в Испании число университетов сократилось до 10 [9].

К XIX в. сформировались две основных модели университета: немецкая и французская. Кроме них развивались и второстепенные модели, такие как британская, американская и российская.

Немецкая модель университета заключалась в реализации идеи Вильгельма фон Гумбольдта классического университета научно-исследовательского типа. Классическим университет назывался еще потому, что «изначально выступал в роли образца, мерила для сравнения» [10, с. 56-57]. Такая модель в дальнейшем получила название «модель 2.0». Фундаментальные принципы университета Гумбольдта - это академическая свобода и единство исследования и преподавания.

Гумбольдт выделял три принципа идеи университета:

- отрицание такого воззрения на образование, когда знания ценят не ради них самих, а ради их практической пользы;

- отрицание господства эмпирической науки, т. к. это стало бы противодействовать фундаментально-теоретическому познанию;

- утверждение, что без гуманитарного образования не может быть образованной личности, а без развития нравственных убеждений и интересов научные знания перерастут в духовный материализм [10].

По такому принципу был создан в 1810 г. Берлинский университет. В дальнейшем по образцу Берлинского университета были модернизированы все остальные университеты Германии. Большинство стран мира, и в первую очередь Россия, приняли эту модель для развития системы высшего образования. Таким образом, университет был представлен как место свободной научной работы. Профессора излагали не устоявшиеся истины, а результаты своих собственных исследований. 
Доминирование гумбольдтовской идеи университета в Европе продолжалось вплоть до середины XIX в. и способствовало тому, что немецкий язык стал преобладающим в европейской науке и образовании, а культурная миссия рассматривалась как главная миссия университета [11]. В результате реформы образования начала XIX в. немецкие университеты стали структурой, позволявшей объединить научное исследование и преподавание. Кроме того, демократическое устройство учебного и научного процесса сделало университет своего рода инкубатором для появления новых талантов в науке. Лекции заменили старую форму истолкования канонических текстов, появились университетские семинары [11].

Если в общем описывать модель университета 2.0, то характерными ее чертами можно считать объединение образовательной и научной функций университета; формирование благоприятной среды для развития инновационной деятельности; подготовку квалифицированного специалиста по существующим запросам экономики [12].

Говоря о французской образовательной модели, к основным положениям можно отнести следующие:

- все люди от природы обладают Разумом, а не только избранные; права индивида защищает Естественное право;

- в основе познавательного процесса лежит личный интерес: каждый человек ищет для самого себя правильный путь;

- отстаивание личных интересов должно способствовать всеобщему благу и развитию;

- обеспечение свободы личности и права собственности должно быть основным приоритетом государства [13].

Во Франции наряду с университетами начинают открываться учебные учреждения, целью которых становится обучение профессиям, связанным с умственным трудом. Особо выделяется инженерное дело. Институциональная модель французских «Больших школ» получает свое окончательное оформление при Наполеоне [3].

Таким образом, французская модель образования сформировалась как результат развития либеральных тенденций в образовании, в том числе с использованием элементов реализации позитивных факторов демократическо-тоталитарных принципов управления обществом. Эта модель явилась основой стабилизации образовательного процесса. Частное образование обеспечило реализацию либерального принципа в образовательном пространстве.

Британская модель университета связана с именем Дж.Г. Ньюмена, основателя католического университета в г. Дублине. Он представил основы концепции университета в своей работе «Рассуждения о целях и природе университетского образования», более известной как «Идея университета» [14]. Дж. Ньюмен стремился найти критерии целостного совмещения практического и теоретического познания. Он обозначил цели и направленность университетского образования и представил университет как пространство активного общения. Доминирующей целью университета по модели Ньюмена является не одностороннее транслирование информации от преподавателя студенту, а предоставление возможности научиться мыслить самостоятельно, а также посмотреть на мир науки не только со стороны, но и погрузиться в нее. Таким образом, Дж. Ньюменом была создана концепция университета либеральных искусств, миссия которого состоит в сосредоточении и транслировании духовного богатства общества [15].

Несмотря на то, что смысловые основы классического университета заложили фундамент институционального устройства современных вузов, глобальные социокультурные трансформации, сопровождавшие индустриализацию, поставили под со- 
мнение возможность их воплощения в реальных условиях XX в. К XX в. в большинстве стран, где активно развивалось промышленное производство, церковь утратила свое влияние на систему высшего образования. Университеты были ориентированы на интересы производства, которое нуждалось в подготовленных специалистах. За счет этого увеличилось количество теоретиков и практиков. Активнее всего этот процесс происходил в США. Развитие института высшего образования в Америке в большой степени зависело и от особенностей формирования нового американского общества. Именно в США в начале XX в. появлялись первые концепции идеального университета, в которых раскрывались позитивные и негативные стороны института высшего образования. Одна из концепций, посвященная роли и месту высшего образования в обществе, принадлежит Торстейну Веблену [16]. Им был показан социальный характер прагматизма, согласно которому основу общественных преобразований составляют эволюционные изменения в характере социальных институтов, создаваемых людьми. Веблен предложил использовать не диалектические законы исторического развития, а схему бесконечного эволюционного существования [17]. Он сформулировал новую модель идеального университета, которую обозначил как «корпорация ученой аристократии». В рамках этой модели университет представлен как особый социальный институт высшего знания, основной задачей которого является сохранение и расширение области познания. Две стороны деятельности университета, которыми считались научное исследование и обучение студентов - должны быть тесно связаны между собой. Веблен писал, что существенной функцией университета является сведение в одном месте для передачи опыта мудрецов прошлого и избранной молодежи нового поколения [18].

Еще одну концепцию развития университета представил А. Флекснер. В соответствии с ней идеальный университет реализует не только исследовательскую функцию, но может быть представлен как специализированная и передовая исследовательская лаборатория. Кроме того, необходимо сосредоточить внимание на четырех основных направлениях его деятельности: научные исследования, оценка достижений науки и техники, внимание к социальным проблемам и подготовка ученых. Главная задача университета заключается в создании методологии для общественных наук. Необходимо это для того, чтобы прогресс технических и естественных наук продолжался совместно с развитием общественных наук [17].

Что касается Российской модели образования, то по проекту и при активном участии М.В. Ломоносова и по указу Елизаветы Петровны были сформулированы основные положения политики в сфере образования и в 1755 г. учрежден Московский университет. В основу университетской образовательной модели в России до революции была заложена немецкая модель В. фон Гумбольдта. Образование было направлено на преодоление авторитарности, заучивание учебного материала, игнорирование интересов личности (причем как преподавателя, так и студента), преобладание средств над целью, цели над смыслом и негибкости системы образования. Одним из условий модели выступала значимость преподавания на русском языке, замена преподавателейиностранцев национальными профессорами, а также необходимость обеспечения связи теоретического материала с практикой в обучении.

Появление университетов в России позволило завершить модель образовательной системы, представленной тремя базовыми элементами образования: «гимназияуниверситет-академия» [19]. Изначально на получение образования было введено сословное ограничение: получать гимназическое образование могли только дети дворян и чиновников. В качестве основных дисциплин были представлены латынь, иностранные языки (французский и немецкий), география, история, начальный курс философии и 
изящных наук, а также математика, литература и начальный курс экономической теории. Изучение латыни было обязательным с первого класса. Кроме того, особое внимание уделялось изучению «Закона Божьего» и греческому языку. Реальные потребности общества не учитывались.

Официальная концепция образования в России, предполагающая единство самодержавия, народности и православия, сложилась примерно к 40-м гг. XIX в. В.В. Розанов, анализируя систему образования в России, предложил свою модель преподавания знаний. Данная модель предполагала выделение двух направлений: формальное образование и реальное. Формальное образование было необходимо для общего развития познавательных способностей человека, а реальное - для формирования индивидуальных свойств личности [20].

Таким образом, к началу 60-х гг. в России открылось семь университетов. Помимо классических возросло количество высших технических учебных заведений. Важным для развития системы высшего образования в стране явилось введение высшего женского образования. Благодаря таким реформам к концу XIX в. уровень грамотности населения поднялся на 16 \% по сравнению с серединой этого века.

В середине XX в. университеты приспособились к новым условиям социокультурной реальности, прежде всего через процессы дифференциации. Кроме того, во многих странах мира произошло изменение систем высшего образования. Наряду с традиционными университетами стало появляться большое количество учреждений нового типа - технических институтов с более короткими программами образования, колледжей, политехникумов, центров дистанционного обучения. Все это создало новые возможности для удовлетворения растущего общественного спроса на получение образования, в том числе высшего. Под влиянием социальных изменений на Западе сформировались три вида систем высшего образования: унитарные, бинарные и тернарные системы. Унитарные включали в себя только университеты. К бинарным относились системы как университетского, так и неуниверситетского образования. А в тернарные системы начали входить университеты или колледжи, а также политехнические институты или краткое, сокращенное послесреднее образование [21].

В XX в. вся система управления университетами была вынуждена адаптироваться к новым условиям, в основе которых лежали принципы рыночной экономики. Вузы оказались в состоянии конкурентной борьбы за государственные заказы на подготовку специалистов, способных эффективно работать в новых рыночных условиях. Велась борьба за потребителя образовательных услуг, готового самостоятельно оплачивать эти услуги, а также за средства на проведение научных исследований, которые предоставлялись как государственными, так и частными фондами. Университеты включились в рыночную борьбу за продвижение высокотехнологичной продукции, изготавливаемой в вузах или ассоциированных с ними производственных структурах наравне с производственными предприятиями [22].

Университет рубежа веков часто называют главным агентом по предоставлению различных услуг населению. Причем производство образовательных услуг является важной, но далеко не единственной деятельностью современных университетов. В них развивается наука, совершенствуются технологии производства. Университет становится не теоретической конструкцией, а реальной движущей силой, необходимой для развития экономики, политической власти, армии, культуры. По мнению Даниэла Белла, университет становится главным социальным институтом современного общества, а также осуществляет большое количество функций в области фундаментальных научных исследований и развитии общего образования, кроме того, выступает как институт 
обеспечения потребностей общества в высококвалифицированных кадрах [23]. В середине XX в. в России отмечался большой подъем университетского образования. Успехи в науке, изучении космоса, развитии ядерной энергетики, а также другие достижения подняли престиж высшего образования.

В конце XX в. для университетов в их классическом понимании наступило время нестабильности. Высшие учебные заведения вынуждены были проводить преобразования под влиянием внешних факторов для сохранения качества образования. В классическом университете образовательный процесс был направлен на получение знаний, ориентированных на красоту и логичность научной теории, а базой новой образовательной модели стала служить информация, дающая возможность ориентироваться в быстро меняющемся потоке знаний, адаптироваться и находить возможности для самореализации в состоянии постоянного изменения.

В 80-е-90-е гг. XX в. происходит сближение гуманитарного и технического образования, возрастает сотрудничество университетов разных стран за счет постоянного обмена студентами и преподавателями. Кроме того, разрабатывается большое количество новых научных проектов учебных планов. С 1992 г. произошли большие перемены в системе высшего образования России. В связи с распадом СССР и вместе с ним единой вузовской системы началось строительство новой системы образования в пределах границ каждой из 15 республик, образованных на территории бывшего СССР. В то же время в России появилось много специалистов высокой квалификации, выехавших с территории новых образовавшихся государств. В связи с этим в Российской Федерации обозначились новые тенденции развития системы высшего образования. Во-первых, начали преобразовывать узкоспециализированные институты в университеты. Так за один год количество университетов выросло с 48 до 97. Во-вторых, произошла популяризация гуманитарных специальностей. В связи с этим уже в 2000-е гг. произошло насыщение рынка профессий, связанных с юриспруденцией и экономикой.

Существенной реформой системы всего высшего образования того времени является создание единого европейского пространства высшего образования, принятого в соответствии с Болонской декларацией «Зона европейского высшего образования» в 1999 г., определившей основные цели, ведущие к достижению сопоставимости и в конечном счете гармонизации национальных образовательных систем высшего образования в странах Европы. С этой декларации и начинается Болонский процесс. Основные положения заключаются:

- в системе легко понимаемых и сопоставимых степеней; внедрении общеевропейского приложения к диплому для обеспечения возможности трудоустройства европейских граждан и повышения международной конкурентоспособности европейской системы высшего образования;

- введении достепенного (udergraduate) и послестепенного (graduate) циклов системы. Доступ ко второму циклу требует успешного завершения первого цикла обучения продолжительностью не менее трех лет. Степень, присуждаемая после первого цикла, должна быть востребованной на европейском рынке труда как квалификация соответствующего уровня. Второй цикл должен вести к получению степени магистра и/или степени доктора, как это принято во многих европейских странах;

- внедрении европейской системы перезачета зачётных единиц трудоёмкости (ECTS) как необходимого средства поддержки крупномасштабной студенческой мобильности. Кредиты могут быть получены также и в рамках образования, не являющегося высшим, включая обучение в течение всей жизни (lifelong learning - LLL), если они признаются принимающими заинтересованными университетами [24]; 
- содействии мобильности; эффективном осуществлении свободного передвижения. Кроме того, учащимся должна быть предоставлена возможность получения образования и практической подготовки. Преподавателям, исследователям и административному персоналу необходимо засчитывать затраченное время на проведение исследований, преподавание и стажировку в европейском регионе, без нанесения ущерба правам, установленным законом;

- разработке сопоставимых критериев и методологий в обеспечении качества образования;

- содействии необходимым европейским воззрениям в высшем образовании, особенно относительно развития учебных планов, межинституционального сотрудничества, схем мобильности, совместных программ обучения, практической подготовки и проведения научных исследований [25]. В 1999 г. в Болонский процесс вступило 30 стран, а в течение последующих 10 лет присоединилось еще 17. Таким образом, в Болонский процесс вступило 47 стран. Создание Болонского процесса повлияло на реформацию идеи университета.

В 2003 г. Российская Федерация присоединилась к Болонскому процессу. Благодаря этому российские университеты начали представляться на мировом рынке образовательных услуг. Процесс сопоставления с зарубежными вузами предполагает единую систему критериев оценки деятельности университетов, а также необходимость разработки собственной независимой, но отвечающей международным стандартам системы рейтингов вузов.

В начале XXI в. классические университеты практически перестают существовать. В связи с этим возникает необходимость развития многопрофильных университетов для успешной адаптации к стремительно меняющимся реалиям и рынку образовательных услуг, а также появлением потребности в массовой подготовке специалистов высшей квалификации в различных сферах деятельности [26]. В Российской Федерации начиная с 2005 г. начал действовать и развиваться приоритетный национальный проект «Образование», в соответствии с которым определились приоритетные направления развития системы образования, были определены лучшие инновационные программы и выделено субсидирование на их развитие.

Университет XXI в. можно отнести к университету третьего поколения. Становление высшего образования 3.0 является одним из главных социальных изменений современной эпохи. Наряду с университетом 1.0, выполняющим функцию образования, и университетом 2.0, совмещающим обучение и исследования, университет 3.0 дополнительно берет на себя миссию социального и экономического развития. Успех ее реализации предопределяет развитие общества знаний, т. е. такого общества, где на первый план выходят осознание роли знания как успеха в любой сфере деятельности; наличие у общества постоянной потребности в новых знаниях, необходимых для решения новых задач, создания инновационных продуктов, услуг; эффективное функционирование систем производства и передачи знаний; эффективное взаимодействие общества, образовательных организаций и предприятий. Одной из важнейших составляющих этой академической миссии является коммерциализация знаний. Она включает инновационно-предпринимательскую деятельность, в том числе преобразование результатов науки в коммерческий продукт, вывод его на рынок, создание новых бизнесов, коммерческое управление интеллектуальной собственностью, использование интеллектуальных ресурсов университета в экономике регионов [27]. Будучи сложной самоорганизованной системой, современный университет объединяет в себе фундаментальное образование и исследовательский процесс, а также усиливает практико-ориентированную направленность вуза и трансформирует традиционные структуры в предпринимательские. 
Концепция «Университет 3.0» предполагает создание на базе университетов интегрированной предпринимательской экосистемы, в которой они становятся ключевыми поставщиками инноваций. Это означает переход к проактивной модели генерации технологий, талантов, рынков и рыночных сервисов, в рамках которой университеты превращаются в градообразующие центры экономических кластеров. По сути, они начинают выступать в роли экономических агентов, крупных компаний, которые умеют управлять результатами интеллектуальной деятельности и хорошо понимают принципы функционирования новых рынков.

Несмотря на то, что идея университета модели третьего поколения считается инновационной, многие современные исследователи системы высшего образования давно говорят о её кризисе. Специфика кризисных тенденций в сфере высшего образования во многом может быть выражена процессами массовизации современного университета. Массовый университет не нацелен на подготовку научно-технической элиты или на подготовку кадрового резерва для существующих на рынке труда профессий, как это было раньше. Наука сегодня слишком специализирована и прагматизирована, и это не позволяет большинству университетских преподавателей совмещать в себе две роли (преподавателя и учёного). Среднестатистический преподаватель университета выполняет в большей степени не функции профессионального ученого, а решает педагогические прикладные задачи. Они заключаются в воспитании и общей подготовке студентов к условиям жизни в социуме; развитии универсальных навыков выполнения трудовых задач (концентрация внимания на проблеме, поиск вариантов её решения); адаптации к работе в коллективе и т. д. Стандартный массовый университет сейчас представляет собой продолжение среднешкольного образования и превращается в закономерный элемент высшей школы. Такие трансформации университетского образования вызывают большое количество проблем. Многие проблемы современного массового университета связаны, с одной стороны, с отказом представителей власти и менеджмента в сфере высшего образования принимать сугубо педагогическую роль университета, а с другой - с узкоутилитарным подходом государства к научной деятельности [28].

Университеты 3.0 - это место, где преподаватели не просто носители знания, но и реальные предприниматели, которые коммерциализируют разработки вуза через созданную экосистему поддержки стартапов на базе университетов. С одной стороны, это создает дополнительный источник дохода для университета, с другой - увеличивает число компетенций, которые могут передаваться студентам.

На сегодняшний день формируется модель университета 4.0. Пока нет устоявшейся терминологии и определения модели 4.0, но уже разрабатываются различные концепции данной модели.

Так, в статье Е.Б. Кузнецова и А.А. Энговатовой «Университеты 4.0: точки роста экономики знаний в России» говорится о том, что «Университет 4.0 - это институт общества, реализующий функцию поставщика знаний о будущем. Лидер развития высокотехнологичных отраслей» [29, с. 6]. Современный университет постепенно трансформируется, и это уже сейчас проявляется во внедрении «Shared governance» (система общего управления); формировании предпринимательской стратегии университета и взаимодействии с группами стейкхолдеров; включении предпринимательских компетенций в перечень знаний и навыков, формируемых у студентов; политике трансферта знаний и технологий; интернационализации университетов [29].

А.В. Нестеров в статье «Чем отличается университет 4.0 от университета 3.0: критические размышления» говорит о том, что в современном университете новым трендом становится способность готовить выпускника, умеющего формулировать задачу на 
профессиональном языке и решать ее с помощью технологии блокчейн. Но возникает большая проблема в том, что блокчейн, который можно использовать в обучении, требует наличия криптоблаг (криптовалюты) и государственных (муниципальных, университетских) реестров [30]. Но в то же время уже сегодня можно наблюдать развитие образовательных хабов, сетевых сообществ и ряда других новейших форм организации жизнедеятельности университетов, также получают стремительное развитие открытые образовательные ресурсы с вариативными комбинациями обучения [31].

Современные технологии уже сейчас требуют от университетов перестройки структуры и сущности образования. Целевой установкой постепенно становятся способы «вскрытия» талантов человека и «прошивки» его жизненных сценариев через синтез биологии и «умных технологий», а также развитие ноосферы. В ближайшем будущем цифровые приложения (скрипты) полностью адаптируются под потребности человека и окончательно вытеснят классические образовательные программы и линейный способ передачи информации [7]. Университет прекратит только двухмерное существование в физическом пространстве, расширяя свое присутствие в виртуальной реальности посредством облачных технологий, в том числе в формате сетевого партнерства с распределенным управлением. Ключевыми категориями станут «Творчество» (человек, выступающий в роли Творца, создателя и созидателя), «Экосистема», развитие (а иногда и создание) которой станет одной из ключевых образовательных целей и «Бизнес» (как регулятор межинституциональных отношений). Формальная система оценивания прекратит существование, а оценкой результативности освоения образовательных программ вне зависимости от исследуемого феномена выступит жизнеспособный продукт, сконструированный студентом, либо релевантный вклад в развитие локальной экосистемы общества [32].

Современная система высшего образования Российской Федерации находится в переходном состоянии от модели 3.0 к 4.0. Кроме того, сформировались определенные тенденции развития высшего образования, такие как:

- потребительское отношение к университетскому образованию, т. е. ключевыми параметрами выбора учебного заведения становятся известность бренда университета, занимаемые позиции в рейтингах, статусность и престижность обучения;

- создание гармоничной инфраструктуры (удобство расположения корпусов, общежитий);

- наличие в учебном плане специальных предметов, недоступных студентам других вузов;

- соответствие выпускника требованиям рынка труда;

- высокий уровень технологического оснащения университета, в том числе, наличие возможности дистанционного образования, оперативная доступность преподавателя, активное внедрение и развитие цифровой экономики [33].

Сегодня большую роль в формировании университета будущего играют: повышение роли преподавателя в образовательном процессе, возможность трансформации университета, уменьшение значимости научной составляющей в формате обучения с использованием дистанционных технологий, адаптация университета для life-long learning, т. е. обучения на протяжении всей жизни [34]. Кроме того, прослеживаются тесная взаимосвязь между образованием и экономическими показателями в повышении общих знаний и навыков населения, генерации специалистов, коммерциализации результатов интеллектуальной деятельности, создании стартапов, спин-оффов и т. д., а также передача новых знаний и идей. Самым важным на сегодняшний день является именно качество обучения, а не количество времени, затраченного на его получение [35]. 
Подводя итоги анализа на основе исторического метода, можно сделать вывод о том, что определение ключевых характеристик современных университетов, способствует успешной адаптации к постоянно меняющимся запросам общества. Другими словами, для трансформации современных университетов необходимо создавать адаптивную по отношению к внешней среде систему управления университетом. Это подразумевает способность вуза оперативно реагировать на изменения законодательства, рынка труда, запросов абитуриентов, повышение стандартов в той или иной отрасли, увеличение конкуренции и оперативно вносить коррективы в свою деятельность.

\section{СПИСОК ЛИТЕРАТУРЫ}

1. Предпосылки возникновения университетов. URL: https://vuzlit.ru/574464/predposylki_ vozniknoveniya_universitetov (дата обращения 01.07.2019).

2. Роуг В. Университет как явление средневековой культуры // Вестник высшей школы (Alma mater). 1991. - № 7. - С. 97-109.

3. Строгецкая Е.В. Динамика институциональной модели университета в условиях социокультурных изменений // Вестник СПбГУ. - 2015. - Вып. 3. - С. 142-150.

4. Огольцова Е.Г., Теплищева А.А., Шуликова П.С. Зарождение университетского образования в Западной Европе // Молодой ученый. - 2017. - № 50. - С. 246-252.

5. Первые университеты - Uversitas magistrorum et scholarum. URL: http://vseon.com/analitika/prostyeistorii/95-i (дата обращения 10.07.2019).

6. Становление и развитие учреждений высшего образования в Западной Европе в XI-XVIII вв. URL: https://www.rsu.edu.ru/wp-content/uploads/e-learning/ZUMK-razvitie-vishego-pedagogicheskogoobrazovaniya-za-rubezhom-i-v-rossii/02.htm (дата обращения 10.07.2019).

7. Леднев В.С. Содержание образования. Сущность, структура, перспективы. - М.: Высшая школа, 1991. $-223 \mathrm{c}$.

8. Мандель Б.Р. Педагогика высшей школы: история, проблематика, принципы. - Москва; Берлин: Директ-Медиа, 2017. -619 с.

9. Jahrhundert zum Zweiten Weltkrieg 1800-1945// Geschichte der Universität in Europa - Gesamtwerk. In 4 Bänden: Geschichte der Universität in Europa. Bd. 3. - W. Rüegg (Hg.). - 1993. - 607 p.

10. Скрипник К.Д. Великая Хартия университетов и исторические основания ее принципов. URL: http://elar.urfu.ru/bitstream/10995/30243/1/iurp-2015-135-06.pdf (дата обращения 12.07.2019).

11. Панькова Н.М. Концепутализация модели университета В. фон Гумбольдта // Трансформация научных парадигм и коммуникативные практики в информационном социуме. - Томск: ТПУ, 2012. C. $150-153$.

12. Пономарева О.Н. Роль современных моделей университетов в формировании человеческого капитала // Региональная общественная организация «Центр инновационных технологий и социальной экспертизы». - 2019. - № 5. - С. 344-353.

13. Меньшиков B.M. Развитие образования в Западной Европе в XVII-XVIII вв. URL: https://www.portalslovo.ru/pedagogy/41983.php (дата обращения 11.07.2019).

14. Ньюмен Дж.Г. Идея университета. - Минск: БГУ, 2006. - 208 с.

15. Кокоревич М.Н., Бадин В.А., Репета А.И. Технический университет в образовательной традиции XX века // Вестник Томского государственного педагогического университета. - 2006. - № 12. C. $45-48$.

16. Сафронова В.В. Современный университет как социальный феномен: концептуальный подход: дис. ... канд. филос. наук. - Кемерово, 2006. - 126 с.

17. Степанова С.Н. Трансформация «идеи университета» в эволюционирующем образовательном пространстве: дис. .... канд. филос. наук. - Томск, 2010. - 152 с.

18. Белая Г.В. Управление образовательным процессом в педагогическом университете: теория и практика: дис. ... д-ра пед. наук. - Оренбург, 2002. - 382 с.

19. Андреев А.Ю., Посохов С.И. Университет в Российской империи XVIII - первой половины XIX века. - М.: РОССПЭН, 2012. $-671 \mathrm{c}$.

20. Середкина Е.В. Гумбольдтовская модель университета в свете «болонизации» российской модели образования // Классический университет в неклассическое время: Труды Томского государственного университета. Серия культурологическая. - Томск, Изд-во ТГУ. - 2008. - С. 105-107.

21. Байденко В.И. Болонский процесс: структурная реформа высшего образования Европы - М.: ИЦПКПС, 2003. - 126 с. 
22. Панькова Н.М., Халдеева М.А., Погукаева Н.В. Коммодификация знания в системе высшего образования // Вестник науки Сибири. - 2017. - № 3 (26). - C. 81-89. URL: https://cyberleninka.ru/article/ n/kommodifikatsiya-znaniya-v-sisteme-vysshego-obrazovaniya/viewer (дата обращения 11.07.2019).

23. Белл Д. Грядущее постиндустриальное общество. - М.: Academia, 2004. - 944 с.

24. Болонский процесс и Болонская декларация. URL: http://www.inf.tsu.ru/WebDesign/bpros.nsf/ news/0109200514 (дата обращения 11.07.2019).

25. The Bologna Declaration of 19 June 1999. URL: https://www.eurashe.eu/library/modernisingphe/Bologna_1999_Bologna-Declaration.pdf (дата обращения 11.07.2019).

26. Карпенко М.П. Перспективы развития системы высшего образования в XXI веке // Знание. Понимание. Умение. - 2006. - № 2. - С. 80-85.

27. Карпов А.О. Университет 3.0 - социальные миссии и реальность // Социологические исследования. 2017. - № 9. - С. 114-124.

28. Богданов А.И. Эволюция идеи университета: прошлое, настоящее, будущее. URL: https://www.science-education.ru/pdf/2015/1/1598.pdf (дата обращения 11.07.2019).

29. Кузнецов Е.Б., Энговатова А.А. «Университеты 4.0»: точки роста экономики знаний в России // Инновации. - 2016. - № 5 (211). - С. 3-9.

30. Нестеров А.В. Чем отличается университет 4.0 от университета 3.0: критические размышления. URL: https://nesterov.su/\%D1\%87\%D0\%B5\%D0\%BC-

$\% \mathrm{D} 0 \% \mathrm{BE} \% \mathrm{D} 1 \% 82 \% \mathrm{D} 0 \% \mathrm{BB} \% \mathrm{D} 0 \% \mathrm{~B} 8 \% \mathrm{D} 1 \% 87 \% \mathrm{D} 0 \% \mathrm{~B} 0 \% \mathrm{D} 0 \% \mathrm{~B} 5 \% \mathrm{D} 1 \% 82 \% \mathrm{D} 1 \% 81 \% \mathrm{D} 1 \% 8 \mathrm{~F}-$ $\% \mathrm{D} 1 \% 83 \% \mathrm{D} 0 \% \mathrm{BD} \% \mathrm{D} 0 \% \mathrm{~B} 8 \% \mathrm{D} 0 \% \mathrm{~B} 2 \% \mathrm{D} 0 \% \mathrm{~B} 5 \% \mathrm{D} 1 \% 80 \% \mathrm{D} 1 \% 81 \% \mathrm{D} 0 \% \mathrm{~B} 8 \% \mathrm{D} 1 \% 82 \% \mathrm{D} 0 \% \mathrm{~B} 5 \% \mathrm{D} 1 \% 8$ 2-4-0-\%D0\%BE\%D1\%82-\%D1\%83\%D0\%BD\%D0\%B8\%D0\%B2\%D0\%B5\%D1\%80/ (дата обращения 11.07.2019).

31. Kaplan A., Haenlein M. Higher education and the digital revolution: about MOOCs, SPOCs, social media, and the Cookie Monster // Business Horizons. - 2016. - V. 59. - Iss. 4. - P. 441-450.

32. Александрова М.А., Лисовская Н.А., Лойко О.Т. Природа и человек: экоориентированные стратегии практик современного образования // Природа и общество: Технологии обеспечения продовольственной экологической безопасности. - Москва: МАКС Пресс, 2016. - С. 82-90.

33. Сантоцкая К.Э. Специфика развития цифровой экономики в системе высшего образования // Перспективы развития фундаментальных наук: сборник трудов XVI Международной конференции студентов, аспирантов и молодых ученых. - Томск: Изд-во ТПУ, 2019. - С. 145-148.

34. Павлова И.А. Трансформация институтов высшей школы и новая социально-экономическая парадигма: роли, функции, взаимодействия современного университета в региональной инновационной системе. - Томск: STT, 2016. - 232 с.

35. The social memory as the value of sustainable tertiary education / A. Kopytova, O. Loyko, V. Sizov, O. Sanfirova // Proc. of the 33rd international business information management association conference, IBIMA 2019: education excellence and innovation management through vision 2020. - Granada, Spain, 10-11 April 2019. - P. 5672-5676.

Поступила 12.08.2019 2. 
UDC 101.1:378.4-029.9

\title{
EVOLUTION OF THE UNIVERSITY IDEA
}

\author{
Ksenia E. Santotskaya1,2, \\ santotskayak@mail.ru \\ ${ }^{1}$ National Research Tomsk Polytechnic University, \\ 30, Lenin Avenue, Tomsk, 634050, Russia \\ 2Tomsk State Pedagogical University, \\ 60, Kievskaya street, 63406, Russia
}

Ksenia E. Santotskaya, graduate student, National Research Tomsk Polytechnic University; senior lecturer, Tomsk state pedagogical University.

Relevance. The formation of the higher education system and the development of the idea of universities have a long history. Studying the evolution of a university allows us to understand how the development of universities affects the life of society, the organization of students education and evolution in general. Analysis of these ideas contributes to understanding the trends in development of the higher education system. Knowledge of these trends promotes to ability to see the prospects for development of society. Research of the higher education system in the Russian Federation facilitates to understanding the history and forming prerequisites for further development of the higher education system. The study of university models, including modern ones, helps to determine the development vectors of higher education institutions in a transitive society. The aim of the research is to study the changes in the idea of universities and determine the trends of modern university models. Methods: analytical, historical, comparative. Results. The author has identified the development trends of modern universities; studied the prospects and principles of development of the University 4.0 model and its differences from the current model; determined the characteristics of universities that facilitate the successful adaptation of higher education institutions to the constantly changing demands of the modern world.

Key words: University, higher education, university transformation, university model, university development, transitive society, trends in higher education development.

\section{REFERENCES}

1. Predposylki vozniknoveniya universitetov [Background of universities]. Available at: https://vuzlit.ru/574464/predposylki_vozniknoveniya_universitetov (accessed 1 July 2019).

2. Roug V. University as a phenomenon of medieval culture. Vestnik vysshey shkoly (Alma mater), 1991, no. 7, pp. 97-109. In Rus.

3. Strogetskaya E.V. Dynamics of the institutional model of the University in the conditions of social and cultural changes. Vestnik $S P b G U, 2015$, Iss. 3, pp.142-150. In Rus.

4. Ogoltsova E.G., Teplishcheva A.A., Shulikova P.S. The Emergence of University education in Western Europe. Molodoy ucheny, 2017, no. 50, pp. 246-252 In Rus.

5. Pervye universitety - Uversitas magistrorum et scholarum [The first universities - Uversitas magistrorum et scholarum]. Available at: http://vseon.com/analitika/prostye-istorii/95-i (accessed 10 July 2019).

6. Stanovlenie i razvitie uchrezhdeniy vysshego obrazovaniya v Zapadnoy Evrope v XI-XVIII vv. [Formation and development of higher education institutions in Western Europe in the XI-XVIII centuries]. Available at: https://www.rsu.edu.ru/wp-content/uploads/e-learning/ZUMK-razvitie-vishego-pedagogicheskogoobrazovaniya-za-rubezhom-i-v-rossii/02.htm (accessed 10 July 2019).

7. Lednev V.S. Soderzhanie obrazovaniya. Sushchnost, struktura, perspektivy [Content of education. Essence, structure, prospects]. Moscow, Vysshaya shkola Publ., 1991. 223 p. 
8. Mandel B.R. Pedagogika vysshey shkoly: istoriya, problematika, printsipy [Pedagogy of higher education: history, problems, principles]. Moscow, Berlin, Direct-Media Publ., 2017. 619 p.

9. Jahrhundert zum Zweiten Weltkrieg 1800-1945 // Geschichte der Universität in Europa - Gesamtwerk. In 4 Bänden: Geschichte der Universität in Europa. Bd. 3.- W.Rüegg (Hg.). - 1993.- 607p. In Deutsch.

10. Skripnik K.D. Velikaya Khartiya universitetov i istoricheskie osnovaniya ee printsipov [The Great Charter of universities and historical basis of its principles]. Available at: http://elar.urfu.ru/bitstream/10995/30243/1/iurp-2015-135-06.pdf (accessed 12 July 2019).

11. Pankova N.M. Kontseputalizatsiya modeli universiteta V. fon Gumboldta [Conceptualization of the V. Von Humboldt University model]. Transformatsiya nauchnykh paradigm $i$ kommunikativnye praktiki $v$ informatsionnom sotsiume [Transformation of scientific paradigms and communicative practices in information society]. Tomsk, TPU Publ., 2012. pp. 150-153.

12. Ponomareva O.N. The role of modern University models in the formation of human capital. Regionalnaya obshchestvennaya organizatsiya «Tsentr innovatsionnykh tekhnologiy $i$ socialnoy ekspertizy», 2019, no. 5, pp. 344-353. In Rus.

13. Menshikov V.M. Razvitie obrazovaniya v Zapadnoy Evrope $v$ XVII-XVIII vv. [Development of education in Western Europe in the XVII-XVIII centuries]. Available at: https://www.portalslovo.ru/pedagogy/41983.php (accessed 11 July 2019).

14. Nyumen Dzh.G. Ideya universiteta [The Idea of the University]. Minsk, BGU Publ., 2006. 208 p.

15. Kokorevich M.N., Badin V.A., Repeta A.I. Technical University in the educational traditions of the XX century. Vestnik Tomskogo gosudarstvennogo pedagogicheskogo universiteta, 2006, no. 12, pp. 45-48. In Rus.

16. Safronova V.V. Sovremenny universitet kak sotsialny fenomen: kontseptualny podkhod. Dis. Kand. nauk [Modern University as a social phenomenon: conceptual approach. Cand. Diss.]. Kemerovo, 2006. 126 p.

17. Stepanova S.N. Transformatsiya «idei universiteta» $v$ evolyutsioniruyushchem obrazovatelnom prostranstve: monografiya [Transformation of the «idea of the University» in the evolving educational space: Monograph]. Tomsk, TML-Press Publ., 2012. 128 p.

18. Belaya G.V. Upravlenie obrazovatelnym protsessom v pedagogicheskom universitete: Teoriya $i$ praktika. Dis. Dokt. nauk [Management of educational process in pedagogical University: Theory and practice. Dr. Diss.]. Orenburg, 2002. 382 p.

19. Andreev A.Yu., Posokhov S.I. Universitet v Rossiyskoy imperii XVIII - pervoy poloviny XIX veka [University in the Russian Empire XVIII - the first half of the XIX century]. Moscow, ROSSPEN Publ., 2012. $671 \mathrm{p}$.

20. Seredkina E.V. Gumboldtovskaya model universiteta v svete «bolonizatsii» rossiyskoy modeli obrazovaniya [Humboldt model of the University in the light of «Polonization» the Russian model of education. Classical University in non-classical time]. Trudy Tomskogo gosudarstvennogo universiteta «Klassicheskiy universitet v neklassicheskoe vremya». Seriya kulturologicheskaya [Classical university in non-classical time. Series Proceedings of Tomsk State University. Cultural Studies Series]. Tomsk, TSU Publ., 2008. pp. 105-107.

21. Baydenko V.I. Bolonskiy protsess: strukturnaya reforma vysshego obrazovaniya Evropy [Bologna process: structural reform of higher education in Europe]. Moscow, ITSPKPS Publ., 2002. 126 p.

22. Pankova N.M., Khaldeeva M.A., Pogukaeva N.V. The commodification of knowledge in higher education. Vestnik nauki Sibiri, 2017, no. 3 (26), pp. 81-89. Available at: https://cyberleninka.ru/article/n/ kommodifikatsiya-znaniya-v-sisteme-vysshego-obrazovaniya/viewer (accessed 11 July 2019).

23. Bell D. Gryadushchee postindustrialnoe obshchestvo [Coming post-industrial society]. Moscow, Akademiya Publ., 2004. 944 p.

24. Bolonskiy protsess $i$ Bolonskaya deklaratsiya [The Bologna process and the Bologna Declaration]. Available at: http://www.inf.tsu.ru/WebDesign/bpros.nsf/news/0109200514 (accessed 11 July 2019).

25. The Bologna Declaration of 19 June 1999. Available at: https://www.eurashe.eu/library/modernisingphe/Bologna_1999_Bologna-Declaration.pdf (accessed 11 July 2019).

26. Karpenko M.P. Perspektivy razvitiya sistemy vysshego obrazovaniya v XXI veke [Prospects for the development of higher education in the XXI century]. Znanie. Ponimanie. Umenie, 2006, no. 2, pp. 80-85.

27. Karpov A.O. University 3.0 - social missions and reality. Sotsiologicheskie issledovaniya, 2017, no. 9, pp. 114-124. In Rus.

28. Bogdanov A.I. Evolyutsiya idei universiteta: proshloe, nastoyashchee, budushchee [Evolution of the idea of the University: past, present, future]. Available at: https://www.science-education.ru/pdf/2015/1/1598.pdf (accessed 11 July 2019).

29. Kuznetsov E.B., Engovatova A.A. Universities 4.0: points of growth of the knowledge economy in Russia. Innovatsii, 2016, no. 5 (211), pp. 3-9. In Rus.

30. Nesterov A.V. Chem otlichaetsya universitet 4.0 ot universiteta 3.0: kriticheskie razmyshleniya [What distinguishes the University 4.0 from the University 3.0: critical reflections]. Available at: https://nesterov.su/ 
\%D1\%87\%D0\%B5\%D0\%BC-\%D0\%BE\%D1\%82\%D0\%BB\%D0\%B8\%D1\%87\%D0\%B0\%D0\%B5\% D1\%82\%D1\%81\%D1\%8F-\%D1\%83\%D0\%BD\%D0\%B8\%D0\%B2\%D0\%B5\%D1\%80\%D1\%81\%D0\% B8\%D1\%82\%D0\%B5\%D1\%82-4-0-\%D0\%BE\%D1\%82-\%D1\%83\%D0\%BD\%D0\%B8\%D0\%B2\%D0\% B5\%D1\%80/ (accessed 11 July 2019).

31. Kaplan A., Haenlein M. Higher education and the digital revolution, about MOOCs, SPOCs, social media, and the Cookie Monster. Business Horizons, 2016, vol. 59, Iss. 4, pp. 441-450.

32. Aleksandrova M.A., Lisovskaya N.A., Loyko O.T. Priroda i chelovek: ekoorientirovannye strategii praktik sovremennogo obrazovaniya [Nature and people: the eco-oriented strategy of modern education practices]. Priroda i obshchestvo: tekhnologii obespecheniya prodovolstvennoy ekologicheskoy bezopasnosti [Nature and society: food environmental security technologies: a collection of articles]. Moscow, MAKS Press, 2016. pp. 82-90.

33. Santotskaya K.E. Spetsifika razvitiya tsifrovoy ekonomiki v sisteme vysshego obrazovaniya [Specifics of the digital economy in higher education]. Sbornik trudov XVI Mezhdunarodnoy konferentsii studentov, aspirantov i molodykh uchenykh. Perspektivy razvitiya fundamentalnykh nauk [Prospects for development of basic sciences. Proc. of the XVI International conference of students, graduate students and young scientists]. Tomsk, TPU Publ., 2019. pp. 145-148.

34. Pavlova I.A. Transformatsiya institutov vysshey shkoly i novaya sotsialno-ekonomicheskaya paradigma: roli, funkysii, vzaimodeystviya sovremennogo universiteta $v$ regionalnoy innovatsionnoy sisteme [Transformation of higher education institutions and a new socio-economic paradigm: roles, functions, interactions of the modern University in the regional innovation system]. Tomsk, STT Publ., 2016. 232 p.

35. Kopytova A., Loyko O., Sizov V., Sanfirova O. The social memory as the value of sustainable tertiary education. Proc. of the $33^{\text {rd }}$ international business information management association conference, IBIMA 2019: education excellence and innovation management through vision 2020. - Granada, Spain, 10-11 April 2019. pp. 5672-5676.

Received: 12 August 2019. 